\title{
Great Plains Ladies'-tresses, Spiranthes magnicamporum: Disjunct in Eastern Ontario and a New Orchid Species for the Ottawa District and Lanark County
}

\author{
Joyce M. Reddoch ${ }^{1, *}$, Paul M. Catling ${ }^{2}$, and Allan H. Reddoch ${ }^{1}$ \\ ${ }^{1} 548$ Rivershore Crescent, Gloucester, Ontario K1J 7 Y7 Canada \\ ${ }^{2}$ Biosystematics Research Institute, Central Experimental Farm, Agriculture Canada, Ottawa, Ontario K1A 0C6 Canada \\ *Corresponding author; email: reddoch@magma.ca
}

\begin{abstract}
Reddoch, Joyce M., Paul M. Catling, and Allan H. Reddoch. 2013. Great Plains Ladies'-tresses, Spiranthes magnicamporum: disjunct in eastern Ontario and a new orchid species for the Ottawa District and Lanark County. Canadian Field-Naturalist 127(4): 348-351.
\end{abstract}

We report the discovery of Great Plains Ladies'-tresses, Spiranthes magnicamporum (Orchidaceae), in eastern Ontario, $250 \mathrm{~km}$ east of its previously known eastern occurrence in Ontario. The population of more than 500 flowering plants (in 2013) was confined to Prairie Dropseed, Sporobolus heterolepis, grasslands within the Burnt Lands Alvar. Peak flowering was in late September, two weeks later than that of Nodding Ladies'-tresses, Spiranthes cernua, in the same area.

Key Words: Great Plains Ladies'-tresses; Spiranthes magnicamporum; Ottawa District; Lanark County; eastern Ontario; Burnt Lands Alvar; alvar; disjunct population; range extension

The Great Plains Ladies'-tresses, Spiranthes magnicamporum Sheviak, is an orchid that occurs in the North American Great Plains from extreme southeastern Manitoba to central Texas (Sheviak and Brown 2002). There are also a number of widely spaced disjunct populations, especially eastward, including southwestern Ontario (Sheviak and Brown 2002). There, $S$. magnicamporum has been recorded in 10 counties between Lakes Erie and Huron as far east as the Niagara Region, Wellington County, and Bruce County (Catling 1976; Oldham and Brinker 2009). In 2011, it was found $150 \mathrm{~km}$ farther east, in the Carden Alvar in the City of Kawartha Lakes (M. J. Oldham, personal communication; specimens at the Royal Ontario Museum Herbarium, Toronto, TRT; acronyms follow the Global Registry of Biodiversity Repositories, http://grbio.org). Spiranthes magnicamporum is classified as vulnerable (S3) in Ontario and uncommon (G4) globally (Oldham and Brinker 2009).

On 18 September 2013, PMC discovered this species in The Burnt Lands in eastern Ontario near Ottawa, $250 \mathrm{~km}$ east of the Carden Alvar (ONTARIO: Lanark Co.: $\mathrm{N}$ end of Burnt Lands Provincial Park (Nature Reserve), at 45.26931, -76.19777, 10 October 2013, P. M. Catling 2013-863, DAO 886623). This discovery is the most northeastern disjunct population of S. magnicamporum so far reported and is a new species for the Ottawa District (the area of southeastern Ontario and southwestern Quebec within $50 \mathrm{~km}$ of the Peace Tower on the Parliament Buildings in Ottawa) and for Lanark County (Reddoch and Reddoch 1997; White 2013*).

The Burnt Lands, located $4 \mathrm{~km}$ north and northeast of Almonte, Mississippi Mills, Ontario, is a $15 \mathrm{~km}^{2}$ area of provincially significant flora and fauna (Brunton 1986*). The publicly owned lands within this area, which straddles the boundary between Lanark County and the City of Ottawa, comprise the Burnt Lands
Provincial Park (Nature Reserve). The bedrock is Paleozoic limestone and dolomite of the Ottawa Formation (Bélanger and Harrison 1980). Large open expanses of The Burnt Lands are alvar meadows, areas of natural grassland vegetation in shallow soil over relatively flat calcareous bedrock (Brunton 1986*; Belcher et al. 1992; Catling 1995; Catling and Brownell 1995, 1999). The alvar meadow habitat in the northwestern section is about $2 \mathrm{~km}^{2}$ in extent, with bedrock that is locally flat with gentle slopes between one flat expanse and the next. At the bases of these slopes in moist to wet seepage areas are meadows dominated by the provincially significant (S3) Prairie Dropseed (Sporobolus heterolepis (A. Gray) A. Gray) (Figure 1). The Spiranthes magnicamporum plants are confined to these open meadows as scattered individuals and occasional pairs. (The scientific names marked in boldface above and below are species highly (50-100\%) confined, in southern Ontario, to alvars (Catling 1995, 2013).)

The other major associate for Spiranthes magnicamporum here is the provincially significant (S2-S3; M. J. Oldham, personal communication) Sheathed Dropseed (Sporobolus vaginiflorus (Torr. ex A. Gray) Alph. Wood var. vaginiflorus). Other associates observed within $1 \mathrm{~m}$ of the orchid plants are the grasses Rough Bentgrass (Agrostis scabra Willd.), Kalm's Brome (Bromus kalmii A. Gray), Spike Muhly (Muhlenbergia glomerata (Willd.) Trin.), Wiry Witchgrass (Panicum flexile (Gattinger) Scribn.), and Beaked Dropseed (Sporobolus vaginiflorus (Torr. ex A. Gray) Alph. Wood var. inaequalis Fern.), as well as Crawe's Sedge (Carex crawei Dewey), Blue-eyed Grass (Sisyrinchium montanum Greene), Wild Strawberry (Fragaria virginiana Miller), Northern Bog Violet (Viola nephrophylla Greene), Self-heal (Prunella vulgaris L.), Small Skullcap (Scutellaria parvula Michx.), False Pennyroyal (Trichostema brachiatum L.), Balsam Groundsel 


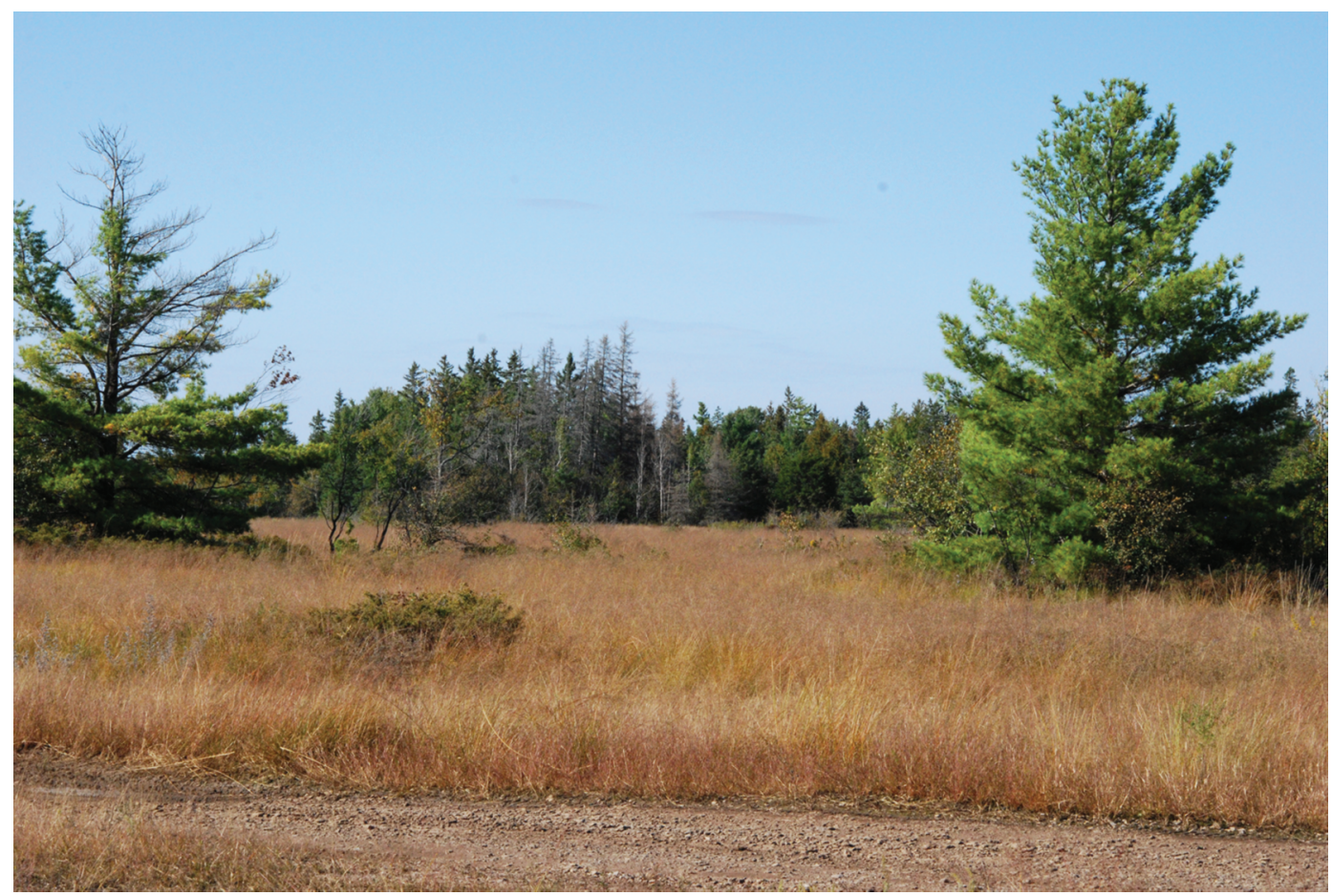

FIgURE 1. Prairie Dropseed (Sporobolus heterolepis) alvar meadow habitat of Great Plains Ladies'-tresses (Spiranthes magnicamporum) in the Burnt Lands Alvar, eastern Ontario, 19 September 2013. The surrounding forest consists of White Spruce (Picea glauca (Moench) Voss), Eastern White Cedar (Thuja occidentalis L.), Balsam Fir (Abies balsamea (L.) Miller), and Eastern White Pine (Pinus strobus L.). Photo: A. H. Reddoch.

(Packera paupercula (Michx.) Á. Löve and D. Löve), and Oxeye Daisy (Leucanthemum vulgare Lam.). The $\mathrm{pH}$ of the moist to wet soils at a few locations where Spiranthes magnicamporum plants were rooted ranged from 7.2 to 7.8, as measured with a Hanna Instruments HI 199121 pH test kit (Hanna Instruments, Woonsocket, Rhode Island).

Five hundred and twenty flowering plants of Spiranthes magnicamporum were counted within an area of $1 \mathrm{~km}^{2}$ on 26 September 2013. At that time, most plants were in full flower, about two weeks later than the peak flowering of Nodding Ladies'-tresses, Spiranthes cernua (L.) Richard, which grows mostly on sands and in moist areas nearby. The heights of a sampling of flowering plants of $S$. magnicamporum ranged from $15 \mathrm{~cm}$ to $30 \mathrm{~cm}$ (mean $21 \mathrm{~cm}, n=38$ ). The flowers (Figures 2 and 3) had a strong, rich, complex, pleasant fragrance. The seeds from three plants were largely monoembryonic but with a small polyembryonic component.

Related species of Spiranthes are pollinated principally by bumble bees (Bombus spp.). Catling (1983) and Smith (2012) reported that S. magnicamporum was also pollinated mainly by this group of insects in Ontario and Minnesota, respectively. Sheviak (1982) reported Golden Northern Bumble Bee, Bombus fervidus, as a pollinator in North Dakota, and Hapeman
(1996*) observed Nevada Bumble Bee, B. nevadensis var. americorum, in Wisconsin. During a two hour afternoon visit to The Burnt Lands site, we observed seven different instances of bumble bees visiting consecutive flowers and sometimes also consecutive plants.

The Prairie Dropseed grasslands in The Burnt Lands are equivalent to grassland habitats in the Great Plains. They are considered to be a relict from early post glacial times (approximately $10000 \mathrm{BP}$ ), when they formed a continuum from the Ottawa Valley westward in front of the receding Wisconsin ice sheet (Catling and Brownell 1995). The presence on The Burnt Lands of a flightless leafhopper (Homoptera: Cicadellidae: Memnonia panzeri) that feeds only on Prairie Dropseed supports this view (Hamilton and Whitcomb 2010). The insect is unlikely to be present in this isolated easternmost habitat unless the habitat was once essentially continuous. Continuity of open habitat in front of the receding ice front is also supported by plant distributions (Catling and Brownell 1995). Prairie Dropseed reaches its northeastern limit in eastern Ontario and southern Quebec (Peterson et al. 2007). The largest stands of this kind of prairie east of disjunct stands in the northern Lake Huron region are on the Burnt Lands Alvar (PMC, personal observation). Considering its narrow confinement to The Burnt Lands and its close 


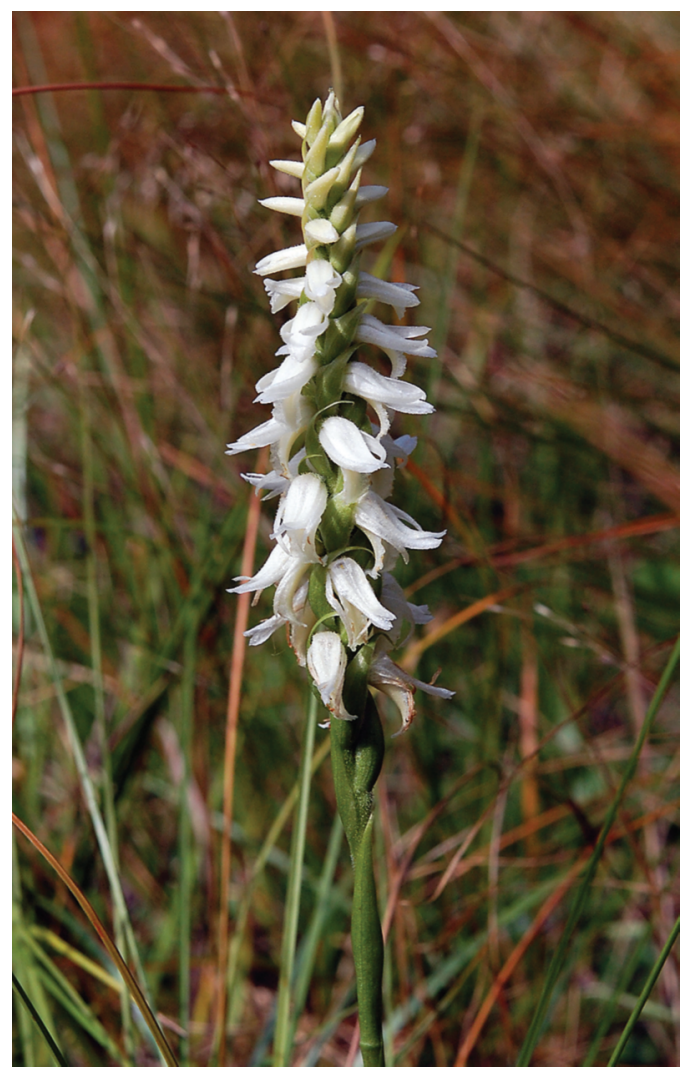

FiguRE 2. Great Plains Ladies'-tresses (Spiranthes magnicamporum) in the Burnt Lands Alvar, eastern Ontario, 19 September 2013. Photo: J. M. Reddoch.

association with the Prairie Dropseed grasslands, Spiranthes magnicamporum may also be an isolated post glacial relict on the Burnt Lands Alvar.

The Flora of North America distribution map for Spiranthes magnicamporum shows seven disjunct populations east of the main range, spaced several hundred kilometres apart (Sheviak and Brown 2002). Given the multiple disjunct populations, it would not be surprising if this species exists in other eastern prairie-like localities, especially those underlain by limestone and dolomite bedrock. The most obvious additional possibilities for disjunct occurrences in the east are the limestone plateaus in New York State east of Lake Ontario. A search for Prairie Dropseed grasslands along the trail in one of these plateaus, the Chaumont Barrens, in 2013, did not reveal any Prairie Dropseed plants, but Prairie Dropseed is extensive in the state and occurs in other places near Chaumont and in the nearby alvars at Lucky Star and Limerick (Catling and Brownell 1995). Remnants of the once extensive alvars of the Napanee Plain in eastern Ontario are also areas of potential occurrence, but Prairie Dropseed grassland is now very limited in this region.

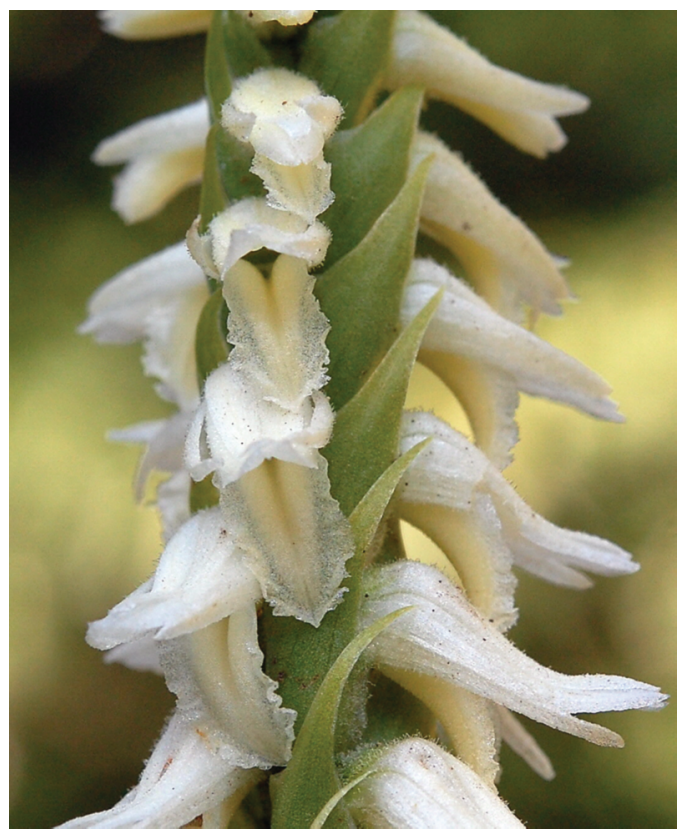

FIgURE 3. Flowers of Great Plains Ladies'-tresses (Spiranthes magnicamporum) in the Burnt Lands Alvar, eastern Ontario, 19 September 2013. Photo: J. M. Reddoch.

It is possible that the drought in 2012 and the very wet summer in 2013 in the eastern Great Lakes region may have resulted in more flowering of Spiranthes magnicamporum than usual. Other rare vascular plant species in eastern Ontario alvars, notably Ram's-head Lady's-slipper (Cypripedium arietinum R. Brown) and Cooper's Milk-vetch (Astragalus neglectus (Torrey \& A. Gray) E. Sheldon), also produced large and robust populations in 2013 (D. F. Brunton, personal communication). Spiranthes magnicamporum may not appear in alvar meadows in some dry years, when alvar vegetation is generally suppressed.

\section{Acknowledgements}

The Ontario Ministry of Natural Resources kindly provided a permit to PMC for research in Burnt Lands Provincial Park. Michael Oldham and Daniel Brunton contributed useful information.

\section{Documents Cited (marked * in text)}

Brunton, D. F. 1986. A life science inventory of The Burnt Lands. Ontario Ministry of Natural Resources, Carleton Place, Ontario. 118 pages +3 maps.

Hapeman, J. R. 1996. Orchids of Wisconsin. An interactive flora. http://www.botany.wisc.edu/orchids/magnicamporum .html (Accessed 5 October 2013).

White, D. J. 2013. Plants of Lanark County, Ontario. 2013 edition. 100 pages. http://www.lanarkflora.com. (Accessed 5 October 2013). 


\section{Literature Cited}

Bélanger, J. R., and J. E. Harrison. 1980. Regional geoscience information: Ottawa-Hull. Geological Survey of Canada. Paper 77-11. Text and maps, including Map 1425A.

Belcher, J. W., P. A. Keddy, and P. M. Catling. 1992. Alvar vegetation in Canada: a multivariate description at two scales. Canadian Journal of Botany 70: 1279-1291.

Catling, P. M. 1976. Spiranthes magnicamporum Sheviak, an addition to the orchids of Canada. Canadian FieldNaturalist 90: 467-470.

Catling, P. M. 1983. Pollination of northeastern North American Spiranthes (Orchidaceae). Canadian Journal of Botany 61: 1080-1093.

Catling, P. M. 1995. The extent of confinement of vascular plants to alvars in southern Ontario. Canadian FieldNaturalist 109: 172-181.

Catling, P. M., and V. R. Brownell. 1995. A review of the alvars of the Great Lakes region: distribution, floristic composition, biogeography and protection. Canadian FieldNaturalist 109: 143-171.

Catling, P. M., and V. R. Brownell. 1999. Alvars of the Great Lakes region. Pages 375-391 in Savannas, Barrens, and Rock Outcrop Plant Communities of North America. Edited by R. C. Anderson, J. S. Fralish, and J. M. Baskin. Cambridge University Press, Cambridge, U.K.

Catling, P. M. 2013. Ecological and geographical separation of three varieties of Sporobolus vaginiflorus (Poaceae) in eastern Ontario. Canadian Field-Naturalist 127: 155-163.

Hamilton, K. G. A., and R. F. Whitcomb. 2010. Leafhoppers (Homoptera: Cicadellidae): a major family adapted to grassland habitats. Pages 169-197 in Arthropods of Canadian Grasslands (Volume 1): Ecology and Interactions in Grassland Habitats. Edited by J. D. Shorthouse and K. D.
Floate. Biological Survey of Canada, c/o Entomological Society of Canada, Ottawa, Ontario.

Oldham, M. J., and S. R. Brinker. 2009. Rare vascular plants of Ontario. Fourth edition. Natural Heritage Information Centre, Ontario Ministry of Natural Resources, Peterborough, Ontario. 188 pages. http://publicdocs.mnr.gov.on.ca /View.asp?Document_ID=15769\&Attachment_ID=3330. (Accessed 5 October 2013 ).

Peterson, P. M., S. L. Hatch, and A. S. Weakley. 2007. Sporobolus R. Br. Pages 212-217 in Manual of Grasses for North America. Edited by M. E. Barkworth, L. K. Anderton, K. M. Capels, S. Long, and M. B. Piep. Utah State University Press, Logan, Utah.

Reddoch, J. M., and A. H. Reddoch. 1997. The orchids in the Ottawa District: floristics, phytogeography, population studies and historical review. Canadian Field-Naturalist 111: $1-185$.

Sheviak, C. J. 1982. Biosystematic study of the Spiranthes cernua complex. New York State Museum, Bulletin 448. 73 pages.

Sheviak, C. J., and P. M. Brown. 2002. Spiranthes Richard. Pages 530-545 in Magnoliophyta: Liliidae: Liliales and Orchidales. Edited by G. W. Argus, K. Gandhi, P. Goldblatt, W. J. Hess, R. W. Kiger, J. L. Strother, F. H. Utech, and J. L. Zarucchi. Vol. 26 of the Flora of North America North of Mexico. Edited by the Flora of North America Editorial Committee, Oxford University Press, New York and Oxford.

Smith, W. R. 2012. Native Orchids of Minnesota. University of Minnesota Press, Minneapolis, Minnesota. 254 pages.

Received 6 October 2013

Accepted 21 October 2013 